\title{
Control of weeds in the japanese pumpkin hybrids
}

\author{
Antonia Mirian Nogueira de Moura Guerra ${ }^{1}$, Maria Gabriela Magalhães Silva ${ }^{1}$, Régila Santos \\ Evangelista $^{1}$, Edeilton Borges dos Santos ${ }^{1}$, Ítalo José da Silva Rodrigues ${ }^{1}$
}

\author{
${ }^{1}$ Universidade Federal do Oeste da Bahia, Campus Barra, Barra, Bahia, Brasil. E-mail: mirianagronoma@hotmail.com, \\ gabi2809@live.com.br, regilasantos10@gmail.com, edeilton17@gmail.com, italo120jsr@gmail.com
}

Received: 28/01/2020; Accepted: 26/04/2020.

\begin{abstract}
The Japanese pumpkin known as "Tetsukabuto" is the result of crossing selected lines of squash. Squashes are highly susceptible to weed interference due to slow initial growth, requiring more considerable attention as to their control. Studies focusing on the losses caused by weeds to Japanese pumpkin hybrids are scarce. Thus, this study aimed to evaluate the influence of weed control on the fruit yield of Japanese pumpkin hybrid cultivars. A randomized block design with four replications in a $3 \times 4$ factorial scheme was used. Three cultivars (Corina F1, Triunfo F1, and Takayama F1) and four weed control periods, without weed control, weed control from 0 to 30 and from 0 to 60 days after transplanting (DAT), and weed control throughout the crop cycle (continuous control) were evaluated. The harvest was carried out at 105 DAT, and it was evaluated population density of the weed community, yield, fruit diameter, fruit fresh mass, number of fruits per plant, pulp thickness, and internal fruit cavity thickness. The weed control from 0 to 60 DAT and continuous weed control resulted in the lowest weed population density and weed dry matter. The weed control from 0 to 60 DAT provided a higher number of fruits per plant, fruit diameter, fruit fresh mass, and thicker pulp. The highest development and fruit yield of Japanese pumpkin hybrids was observed when the plants were free from weed interference until 60 days after transplanting.
\end{abstract}

Keywords: Japanese pumpkin, competition, productivity, Tetsukabuto.

\section{Influência dos períodos de controle de plantas daninhas na cultura das abóboras híbridas japonesas}

\section{RESUMO}

A abóbora híbrida japonesa conhecida como 'Tetsukabuto' é resultante do cruzamento entre linhagens selecionadas de moranga e abóbora. Devido ao crescimento inicial lento, as abóboras são mais suscetíveis à interferência das plantas daninhas, demandando uma maior atenção quanto ao seu controle. São escassos os estudos com foco nas perdas causadas pelas plantas daninhas às abóboras japonesas híbridas. Assim, o objetivo deste trabalho foi avaliar a influência do controle de plantas daninhas sobre a produção de cultivares de abóbora híbrida. Adotou-se o delineamento em blocos com quatro repetições em esquema fatorial 3x4, compreendendo três cultivares (Corina F1, Triunfo F1 e Takayama F1) e quatro períodos de controle de plantas daninhas (sem controle, controle de 0 a 30 , controle de 0 a 60 dias após o transplante mudas - DAT e controle durante todo o ciclo da cultura). A colheita foi realizada aos 105 DAT e avaliou-se: densidade populacional da comunidade infestante, produtividade, diâmetro, massa fresca do fruto, número de frutos/planta, espessura de polpa e da cavidade interna dos frutos. No controle contínuo e de 0 a 60 DAT observou-se menor densidade de plantas daninhas e acúmulo de biomassa seca da parte aérea. $\mathrm{O}$ controle de 0 a 60 DAT proporcionou maior número de frutos/planta, frutos de maior diâmetro, peso e polpa mais espessa. $\mathrm{O}$ melhor desenvolvimento e produtividade de abóbora híbrida japonesa foi obtido quando as plantas ficaram livres da interferência de plantas daninhas por 60 DAT.

Palavras-chave: abóbora japonesa, competição, produtividade, Tetsukabuto. 


\section{Introduction}

Pumpkin and squash are a species of the Cucurbitaceae family, belonging to the genus Cucurbita, composed of 15 species, which are widely known and cultivated worldwide. They are widely consumed because they are considered rich sources of retinol, provitamin A, carbohydrates, B vitamins, calcium, iron, and phosphorus (Priori et al., 2013).

The hybrid pumpkin is known as 'Tetsukabuto', also popularly called Japanese pumpkin or Cabotiá, which is a hybrid resulting from the crossing between selected lines of Cucurbita maxima Duch., adopted as female parents, and lines of $C$. moschata Duch. as male parents. This species was developed in the mid-1940s, in Japan, and was introduced in Brazil in the 1960s (Priori et al., 2013; Bisognin, 2002).

The Japanese pumpkin has agronomic qualities such as precocity, rusticity, uniformity, high production potential, organoleptic quality (texture, flavor, thick and lean pulp, low fiber content, reduced cooking time), and prolonged post-harvest conservation. This culminates with the frank expansion of its areas, the productive success, and the acceptability of this cucurbit when compared to local cultivars of open pollination (Agristar, 2019; Tavares, 1999; Campo \& Negócios, 2010). Its fruits that weigh an average of $2.0 \mathrm{~kg}$, and can reach $3.0 \mathrm{~kg}$, have dark green skin, rounded to slightly flattened shape, being attractive and preferred by the consumer (Nascimento et al., 2011).

This hybrid showed excellent adaptation to Brazilian conditions, assuming great economic importance in Brazil, standing out as the preferred leader among producers, buyers, and the best option in the consumer market. The Japanese pumpkin ranks 28th of commercialization at CEAGESP (Companhia de Entrepostos e Armazéns Gerais de São Paulo), and, in Brazil, the main producing regions are Santa Catarina (30\%), São Paulo (30\%), Minas Gerais (16\%), Bahia (7\%) and Goiás (7\%). In 2016, 33,914 tons of different squash types were marketed, being: Japanese pumpkin (60\%), Pumpkin (20\%), Seca (11\%), and Paulistinha (6\%) (Agristar, 2017).

Squashes had slow initial growth, and their management requires wide spacing between rows (Vidal et al., 2000). Thus, the soil cover takes place more slowly, and the crop is more exposed and susceptible to interference from weeds, requiring greater attention to their control.

Weeds in the producing areas are inconvenient because they cause direct losses due to competition for resources necessary to growth, such as water, nutrients, and light. Also, they can cause indirect damages, for example, hosting pathogens and insects that can cause significant losses to the crop, besides interfering in the fruit yield and quality.
Crop management, including weed control, is fundamental for the production of squashes, and attention should be paid to the critical competition period since it is recommended to keep the crop free from weed interference, especially while flowering is taking place (Sediyama et al., 2009). The main form of weed control is through manual and mechanical weeding. However, these must be used with care to avoid damage to the root system, as well as to prevent branch movement, as it can cause flowers and fruits to fall. Also, in Brazil, there are still no herbicides registered for use as chemical control in this crop (Vidal et al., 2000).

Silva et al. (2013b) observed that weed management (weeding up to 42 days after transplanting), in both notillage (NTS) and conventional tillage systems, contributed to increases in the number of total and commercial fruits per plant, fruit weight, commercial fruit weight, and commercial and total yield. Similarly, Teófilo et al. (2012), studying weed management in the no-tillage and conventional tillage system, obtained similar results.

Studies focusing on the damage and losses caused by weeds to Japanese pumpkin hybrids are scarce, unlike what is found for other cucurbits such as watermelon (Nosratti et al., 2017; Splawski et al., 2016; Silva et al., 2013b; Walters and Jovem, 2010; Fanadzo et al., 2010; Maciel et al., 2008; Medeiros et al., 2000) and Italian pumpkin (Mallet and Ashley, 1988). The availability of this information is essential for management guidance to the pumpkin producers. Thus, this study aimed to evaluate the influence of weed control periods on the production of Japanese pumpkin hybrid cultivars.

\section{Material and Methods}

The experiment was carried out in the experimental area of the Universidade Federal do Oeste da Bahia (the Federal University of Western Bahia), Centro

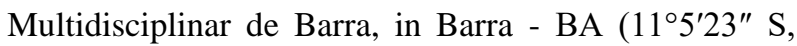
$43^{\circ} 8^{\prime} 30^{\prime \prime} \mathrm{W}$, and $398 \mathrm{~m}$ of altitude). The region climate, according to the Köeppen classification, is the Aw type. Tropical climate with an average temperature of $25.5^{\circ} \mathrm{C}$, the relative humidity of $61 \%$, and precipitation of 335 $\mathrm{mm}$ (marked by irregularity rainfall, and a rainy period from December to February). The experiment was carried out from November 2017 to February 2018, and the average, minimum, and maximum temperature was 27.2, 21.1, and $33.1{ }^{\circ} \mathrm{C}$, respectively, and the accumulated precipitation was $412 \mathrm{~mm}$.

The soil chemical granulometric properties in the 0 $20 \mathrm{~cm}$ layer were $\mathrm{pH}$ in $\mathrm{H}_{2} \mathrm{O}: 5.5$; $\mathrm{P}$ (Mehlich 1): $3.0 \mathrm{mg}$ $\mathrm{dm}^{-3} ; \mathrm{K}: 46 \mathrm{mg} \mathrm{dm}{ }^{-3} ; \mathrm{Ca}^{2+}: 0.9 \mathrm{cmol}_{\mathrm{c}} \mathrm{dm}^{-3} ; \mathrm{Mg}^{2+}: 0.2$ $\mathrm{cmol}_{\mathrm{c}} \mathrm{dm}^{-3} ; \mathrm{H}+\mathrm{Al}: 3.3 \mathrm{cmol}_{\mathrm{c}} \mathrm{dm}^{-3} ; \mathrm{S}: 1.55 \mathrm{mg} \mathrm{dm}^{-3}$; 
base saturation: $57 \%$, organic matter: $1.24 \mathrm{~g} \mathrm{~kg}^{-1}$, sand: $74 \%$, Silt: $11 \%$, and Clay: $15 \%$.

The soil was prepared with an operation of harrowing, and sowing furrows were manually opened with the aid of hoes. The crop fertilization was carried out based on the results of soil chemical analysis and following the recommendations for the pumpkin Tetsukabuto, according to Trani et al. (2014). As fertilization, $120 \mathrm{~kg}$ ha- 1 of $\mathrm{P} 2 \mathrm{O} 5,60 \mathrm{~kg}$ ha- 1 of $\mathrm{K} 2 \mathrm{O}$, and $30 \mathrm{~kg}$ ha-1 of $\mathrm{N}$ were distributed and incorporated five days before transplanting the seedlings. Urea, simple superphosphate, and potassium chloride were used as sources of $\mathrm{N}, \mathrm{P}$, and $\mathrm{K}$, respectively. Also, $15 \mathrm{~kg}$ $\mathrm{ha}^{-1}$ of zinc sulfate, $10 \mathrm{~kg} \mathrm{ha}^{-1}$ of borax, $10 \mathrm{~kg} \mathrm{ha}^{-1}$ of copper sulfate, and $0.5 \mathrm{~kg} \mathrm{ha}^{-1}$ of ammonium molybdate were applied. Two topdressing fertilization with $30 \mathrm{~kg}$ $\mathrm{ha}^{-1}$ of $\mathrm{N}$ and $\mathrm{K}_{2} \mathrm{O}$ were performed at 30 and 60 days after transplanting (DAT). Calcium nitrate and potassium chloride were used as sources of $\mathrm{N}$ and $\mathrm{K}$, respectively.

The hybrid pumpkin cultivars Corina F1, Triunfo F1, and Takayama F1, were used. The seedlings were produced under a protected environment, in 72-cell polystyrene trays, filled with a commercial agricultural substrate (MaxFertil ${ }^{\circledR}$ ) and transplanted at 28 days after sowing, when the seedlings had four leaves.

A randomized block design with four replications in a 3x4 factorial scheme was used. Three cultivars (Corina F1, Triunfo F1, and Takayama F1) and four weed control periods, without weed control, weed control from 0 to 30 DAT, weed control from 0 to 60 DAT, and weed control throughout the crop cycle (continuous control).

The spacing adopted was $2.0 \mathrm{~m}$ between rows and $1.0 \mathrm{~m}$ between plants $(2.0 \times 1.0 \mathrm{~m})$. A row between the plots of pollinating squash, cultivar Expo, was sown. Each plot was composed of six rows of $4.0 \mathrm{~m}$ length; the four central rows constituted the useful area (16.0 $\mathrm{m}^{2}$ ), and the two central plants of each row were evaluated.

During the conduct of the experiment, manual weeding was carried out according to the treatment arrangement. Drip irrigation was adopted on days when there was no precipitation with water depth from 5 to 10 $\mathrm{mm}$, based on the evaporation of the Class A Evaporation Pan. Six sprayings with neem oil at $30 \%$ (Azadirachta indica) were carried out for control of aphids (Aphis gossypii), borer cucurbits (Diaphania sp.) and whitefly (Bemisia sp.).

The harvest was carried out at 105 DAT, when the plants showed yellowing, dry peduncles, and peel resistant to nail penetration, which are indicatives of the harvest point (Filgueira, 2013). In this stage, fruit yield $\left(\mathrm{t} \mathrm{ha} \mathrm{h}^{-1}\right.$ ), fruit diameter $(\mathrm{mm})$, fruit weight ( $\mathrm{kg}$ fruit-1), number of fruits per plant, pulp thickness (mm), and internal fruit cavity thickness ( $\mathrm{mm})$ were evaluated. The evaluations of fruit weight, fruit diameter, pulp thickness, and internal fruit cavity thickness were carried out on five fruits from each plot, which were weighed, cut transversely, and measured with a digital caliper.

At the harvest, population density and dry matter of weeds evaluations were carried out. For this purpose, two samples were obtained in each plot, with $1.0 \mathrm{~m}^{2}$ squares. The weeds were cut at ground level, identified, and separated by species. After quantifying the occurring weed species, they were taken to a forced-air circulation oven, at $65{ }^{\circ} \mathrm{C}$, until constant mass, to determine the dry matter.

The data were subjected to analysis of variance, and the Scott-Knott test was applied to group the means at $5 \%$ probability. Analyzes were performed using the software SISVAR 5.3 (Ferreira, 2011).

\section{Results and Discussion}

The main weed species that occurred most frequently in the experimental area were Commelina benghalensis L. (Bengal dayflower), Acanthospermum hispidum (Bristly starbur), Bidens pilosa (Cobbler's pegs), Portulaca oleraceae L. (Common purslane), Merremia cissoides (Lam.) Hallier f. (White morning glory) and Waltheria americana L. (Sleepy morning) (Table 1).

The strategies of weed control influenced the population density and dry matter of weeds. The weed control from 0 to 60 DAT and continuous weed control resulted in the lowest population density and dry matter of weeds (Table 1). According to Silva et al. (2013b), the lowest weed population density in watermelon cultivation occurred when polyethylene film and weeding was adopted at 14, 28, and 42 DAT. According to Correia et al. (2006), the composition and population density of infesting communities are influenced by production systems. Thus, adopting techniques that restrict the emergence of weeds are strategies to reduce the population density of the weed community and the damage caused by competition during the establishment of the crop.

There was the influence of interaction between cultivars $\mathrm{x}$ weed control periods on all variables, except for the number of fruits per plant and thickness of the internal fruit cavity (Tables 2 and 3 ).

There was no difference between weed control from 0 to 60 DAT and continuous weed control, and both weed control strategies resulted in a higher number of fruits per plant than the other weed control strategies. Pumpkins that remained from 0 to 60 days without weed influence had an increase of $437.02 \%$ in the number of fruits per plant concerning pumpkins without 
weed control. Also, it was observed that the cultivar Corina F1 had a higher number of fruits per plant $(40.44 \%)$ than Takayama F1 and did not differ from Triunfo F1 (Table 2).

The cultivars Corina F1 and Triunfo F1 had fruits with the largest internal cavities; also, plants from the treatment without weed control and plants with weed control from 0 to 30 DAT had fruits with the largest internal cavities (Table 2).

The lowest number of fruits per plant in the treatment with weed control for only 30 days after transplanting was due to the higher competition between pumpkins and weeds so that they prevented and at the same time delayed the growth of the branches, with the consequent reduction in the number of flowers per plant. Also, Freitas et al. (2017) emphasized that the slow vegetative growth of pumpkins has disadvantaged them concerning weeds. Also, the increase in spacing contributed to the production of fewer fruits per area, which is disadvantaged by the lengthening of the stems, in addition to the greater interval for total soil coverage, leaving the crop exposed for longer to competition (Lang and Ermini, 2010). It is worth noting that the higher number of weedings potentiates the harmful effects on the pumpkin yield due to mechanical damage to the roots.
There was the influence of the interaction between cultivars and weed control periods on fruit diameter, fruit yield, and fruit pulp thickness. Weed control from 0 to 60 DAT and continuous weed control resulted in larger and heavier fruits, thicker pulp, and higher yield than the other weed control periods. It was observed that the cultivar Corina with continuous weed control had fruits of larger diameter $(+100.00 \%)$, higher weight $(+$ $587.26 \%)$, and thicker pulp $(+251.11 \%)$ than plants without weed control (Table 3 ).

All cultivars had higher fruit yield when they were maintained without weed interference from 0 to 60 DAT and continuous weed control. The cultivar Corina F1 under the weed control from 0 to 60 DAT, had the highest fruit yield, which was around $84,60 \%$ and $167,76 \%$ superior to the cultivars Takayama F1 and Triunfo F1, respectively. There was no difference among the cultivars when they were kept without weed interference from 0 to 30 DAT. However, the cultivar Corina F1 tended to obtain higher fruit yield than the others. It was notorious how much the fruit yield was influenced by the weed control period, and that if the pumpkins are kept free from weed interference for 60 days, yield increases of $361.3 \%$ will be obtained, on average, when compared to the weed control from 0 to 30 DAT (Table 3).

Table 1. Weed population density (plants $\mathrm{m}^{-2}$ ) (D), weed frequency (Freq), and weed dry matter at the time of harvest of Japanese pumpkin hybrids, according to the periods of coexistence with weeds.

\begin{tabular}{|c|c|c|c|c|c|c|c|c|}
\hline \multirow{2}{*}{ Weed species } & \multicolumn{2}{|c|}{ Continuous control } & \multicolumn{2}{|c|}{ 0 - 60 DAT } & \multicolumn{2}{|c|}{ 0 - 30 DAT } & \multicolumn{2}{|c|}{ Without control } \\
\hline & D & Freq $(\%)$ & D & Freq $(\%)$ & D & Freq $(\%)$ & D & Freq $(\%)$ \\
\hline Setaria parviflora (Poir.) Kerguélen & 2.00 & 4.54 & 3.00 & 4.76 & 23.00 & 7.40 & 31.00 & 8.05 \\
\hline Portulaca oleraceae L. & 6.00 & 13.63 & 8.00 & 12.70 & 29.00 & 9.80 & 44.00 & 11.43 \\
\hline Acanthospermum hispidum & 7.00 & 15.90 & 11.00 & 17.46 & 32.00 & 10.76 & 59.00 & 15.32 \\
\hline Bidens pilosa & 3.00 & 6.83 & 4.00 & 6.35 & 38.00 & 12.75 & 27.00 & 7.01 \\
\hline Commelina bengalensis L. & 10.00 & 22.72 & 11.00 & 17.46 & 43.00 & 14.44 & 54.00 & 14.02 \\
\hline Eleusine indica (L.) Gaertn & 5.25 & 11.94 & 9.00 & 14.29 & 29.00 & 9.80 & 36.00 & 9.35 \\
\hline Waltheria americana $\mathrm{L}$. & 2.75 & 6.25 & 8.00 & 12.70 & 27.00 & 9.15 & 48.00 & 12.46 \\
\hline Digitaria horizontalis Willd. & 3.00 & 6.82 & 4.00 & 6.35 & 30.00 & 10.10 & 38.00 & 9.90 \\
\hline Merremia cissoides (Lam.) Hallier & 5.00 & 11.37 & 5.00 & 7.93 & 47.00 & 15.80 & 48.00 & 12.46 \\
\hline Total & $44.00 \mathrm{~d}$ & 100.00 & $63.00 \mathrm{c}$ & 100.00 & $298.00 \mathrm{~b}$ & 100.00 & 385.00 a & 100.00 \\
\hline Weed dry matter $\left(\mathrm{g} \mathrm{m}^{-2}\right)$ & \multicolumn{2}{|c|}{$2.73 \mathrm{~d}$} & \multicolumn{2}{|c|}{$11.23 \mathrm{c}$} & \multicolumn{2}{|c|}{$192.18 \mathrm{~b}$} & \multicolumn{2}{|c|}{285.75 a } \\
\hline
\end{tabular}

Means followed by the same letter in the lines belong to the same group by the Scott-Knott test at 5\% probability. DAT: days after transplantation.

Table 2. Number of fruits per plant and internal fruit cavity thickness of Japanese pumpkin hybrid cultivars according to the periods of coexistence with weeds.

\begin{tabular}{lcc}
\hline Cultivars & Number of fruits per plant $* *$ & Internal fruit cavity thickness (mm)** \\
\hline Triunfo F1 & $1.78 \mathrm{~b}$ & $72.19 \mathrm{a}$ \\
Takayama F1 & $2.20 \mathrm{a}$ & $64.81 \mathrm{~b}$ \\
Corina F1 & $2.50 \mathrm{a}$ & $76.50 \mathrm{a}$ \\
\hline & Weed control periods $* *$ & \\
\hline Without control & $0.62 \mathrm{c}$ & $89.00 \mathrm{a}$ \\
0-30 days & $1.66 \mathrm{~b}$ & $84.50 \mathrm{a}$ \\
0-60 days & $3.33 \mathrm{a}$ & $70.33 \mathrm{~b}$ \\
Continuous control & $3.01 \mathrm{a}$ & $70.83 \mathrm{~b}$ \\
\hline CV $(\%)$ & 17.98 & \\
\hline
\end{tabular}

Means followed by the same letter in the columns belong to the same group by the Scott-Knott test at 5\% probability. CV: coefficient of variation. ns: not significant. $* *$ and $*$ : significant at $1 \%$ and $5 \%$ probability by the $\mathrm{F}$ test, respectively. 
Table 3. Fruit diameter, fruit weight, fruit yield, and pulp thickness of Japanese pumpkin hybrid cultivars according to the periods of coexistence with weeds.

\begin{tabular}{|c|c|c|c|c|c|c|}
\hline & \multicolumn{3}{|c|}{ Fruit diameter $(\mathrm{mm}) * *$} & \multicolumn{3}{|c|}{ Fruit weight $(\mathbf{k g}) * *$} \\
\hline & Triunfo F1 & Takayama F1 & Corina F1 & Triunfo F1 & Takayama F1 & Corina F1 \\
\hline Without control & $97.50 \mathrm{Db}$ & $97.50 \mathrm{Db}$ & $115.00 \mathrm{Da}$ & $320.00 \mathrm{Da}$ & $312.50 \mathrm{Da}$ & $392.50 \mathrm{Da}$ \\
\hline $0-30$ days & $130.00 \mathrm{Ca}$ & $115.00 \mathrm{Cb}$ & $132.50 \mathrm{Ca}$ & $592.50 \mathrm{Cb}$ & $560.00 \mathrm{Cb}$ & $795.00 \mathrm{Ca}$ \\
\hline 0-60 days & $167.50 \mathrm{Bb}$ & $177.50 \mathrm{Bb}$ & $205.00 \mathrm{Ba}$ & $1135.00 \mathrm{Bc}$ & $1302.50 \mathrm{Bb}$ & $2200.00 \mathrm{Ba}$ \\
\hline Continuous control & $193.00 \mathrm{Ab}$ & 196.50 Ab & $230.00 \mathrm{Aa}$ & $1450.00 \mathrm{Ab}$ & $1517.50 \mathrm{Ab}$ & $2697.50 \mathrm{Aa}$ \\
\hline \multirow[t]{3}{*}{ CV $(\%)$} & & 6.87 & & & 9.85 & \\
\hline & \multicolumn{3}{|c|}{$\begin{array}{l}\text { Fruit yield }\left(\mathbf{t ~ h a}^{-1}\right)^{* * *} \\
\end{array}$} & \multicolumn{3}{|c|}{ Pulp thickness (mm)* } \\
\hline & Triunfo F1 & Takayama F1 & Corina F1 & Triunfo F1 & Takayama F1 & Corina F1 \\
\hline Without control & $0.63 \mathrm{Ba}$ & $1.28 \mathrm{Ba}$ & $1.49 \mathrm{Ba}$ & $44.25 \mathrm{Ca}$ & $43.75 \mathrm{Ca}$ & $45.00 \mathrm{Ca}$ \\
\hline 0-30 days & $3.67 \mathrm{Ba}$ & $4.21 \mathrm{Ba}$ & $9.02 \mathrm{Ba}$ & $42.25 \mathrm{Ca}$ & $34.50 \mathrm{Db}$ & $46.50 \mathrm{Ca}$ \\
\hline 0-60 days & $15.54 \mathrm{Ab}$ & $22.54 \mathrm{Ab}$ & $41.61 \mathrm{Aa}$ & $95.00 \mathrm{Bc}$ & $117.00 \mathrm{Bb}$ & $127.00 \mathrm{Ba}$ \\
\hline Continuous control & $20.19 \mathrm{Ab}$ & $23.04 \mathrm{Ab}$ & $44.21 \mathrm{Aa}$ & $117.00 \mathrm{Ac}$ & $132.00 \mathrm{Ab}$ & $158.00 \mathrm{Aa}$ \\
\hline CV $(\%)$ & \multicolumn{3}{|c|}{33.93} & \multicolumn{3}{|c|}{6.30} \\
\hline
\end{tabular}

Means followed by the same uppercase letters in the columns and lowercase letters in the lines belong to the same group by the Scott-Knott test at $5 \%$ probability. CV: coefficient of variation. ns: not significant. ** and *: significant at $1 \%$ and $5 \%$ probability by the F test, respectively.

The highest means of fruit diameter, fruit weight, yield, and fruit pulp thickness in plants kept free of weed interference for 60 days can be attributed to the higher capacity of plants expand their branches, accumulate biomass, increase leaf area, and subsequent production of photoassimilates besides allowing total soil coverage at the stage when the pumpkins had slow growth.

After 60 days, the branches of the plants had already covered all the spacing between the rows, overcoming the critical period of the competition. Thus, it is assumed that the higher yield of the cultivars evaluated here is similar to that found by Vidigal et al. (2007), who observed in a hybrid pumpkin type Tetsukabuto, cultivar Suprema, a slow growth until 56 DAS. However, from this moment on, the plant presented a higher rate of absolute growth, where the dry matter accumulated in the leaves contributed to accelerating the growing accumulation of dry matter in the plant and fruits.

Also, Silva et al. (2013b) observed that in the absence of weed management, or with only a weeding at 14 or 42 DAT in the cultivation of watermelon, there was no production of marketable fruits, being a consequence of the intense competition exercised by the weeds. This indicates that the watermelon culture requires the realization of two weeding operations until 28 DAT, and from that moment, the weeds that emerge will not interfere in the crop yield. In the melon, Teófilo et al. (2012) also found no weeding effect after 28 DAT.

It was possible to observe differences in fruit diameter and weight and pulp thickness between the cultivars. This performance is due to the genetic characteristics inherent of each genotype, and the lower weed population density competing for water, light, and nutrients. Also, Madeira et al. (2014) observed significant differences between the weight of fruits of the B8A cultivars, followed by Jarbas and Fortuna. They attributed the difference to the distinct genetics of each one.

As reported by Correia et al. (2006), the composition and population densities of infesting communities are influenced by production systems. It was found that regardless of cultivars, within each weed management strategy, the weed control for 60 days after transplanting resulted in a smaller weed population and contributed to the production of fruits that stood out in diameter, weight, pulp thickness, and yield. Corroborating the authors mentioned above, Silva et al. (2013a) found that weeding at 14 and 28 DAT favored the production of fruits with greater mass, diameter, and thickness of the pulp; also, these treatments were those with lower population densities of weeds.

In this way, it can be ensured that, when the ideal conditions for the vegetative development of the plants are maintained, especially if the hybrid pumpkins are kept free from weed interference until the flowering stage, the accumulation of biomass in the leaves and other parts of the plant. The plant will contribute positively to higher photosynthetic rates, fruit set up, and development with higher biomass accumulation, ensuring higher competitive performance and productivity of different genotypes.

\section{Conclusions}

The interference by weeds caused damage both in yield and in the appearance of Japanese pumpkin hybrids fruits.

Weed control from 0 to 30 days after transplanting resulted in the production of fruits with larger internal cavities and less thick pulp.

Weed control from 0 to 60 days after transplanting provided increases of yield in all evaluated cultivars. 
However, the cultivar Corina F1 presented, in isolation, the best results.

It is recommended to keep the plants free from weed interference for at least 60 days after transplanting the seedlings to achieve better plant development and higher yield of Japanese pumpkin hybrids.

\section{Acknowledgments}

To Agristar do Brasil for donating the seeds of Japanese pumpkin hybrids.

\section{Bibliographic References}

Agristar, 2019. Abóbora Takayama Furusato F1: variedade atende todas as regiões do Brasil e se destaca pela alta produtividade. Folha Verde - Informativo da Agristar do Brasil, 28(60), 01-08.

Agristar, 2017. Abóbora Takayama F1 se destaca pela produtividade e adaptabilidade em diferentes solos e climas. Folha Verde - Informativo da Agristar do Brasil, 26(46), 0108 .

Bisognin, D.A., 2002. Origin and evolution of cultivated cucurbits. Ciência Rural, 32(4), 715-723.

Campo \& Negócios HF, 2010. Panorama: Abóbora Tetsukabuto é destaque brasileiro. Revista HF. Agrocomunicação, Uberlândia, 5(57), 25-26.

Correia, N.M., Durigan, J.C., Klink, U.P., 2006. Influência do tipo e da quantidade de resíduos vegetais na emergência de plantas daninhas. Planta Daninha, 24(2), 245-253.

Fanadzo, M., Chiduza, C., Mnkeni, P.N.S., 2010. Pre-plant weed control, optimum $\mathrm{N}$ rate and plant densities increase butternut (Cucurbita moschata) yield under smallholder irrigated conditions in the Eastern Cape Province of South Africa. African Journal of Biotechnology, 5(16), 2192-2199.

Ferreira, D.F., 2011. SISVAR: a computer statistical analysis system. Ciência e Agrotecnologia, 35(6), 1039-1042.

Filgueira, F.A.R., 2013. Novo manual de olericultura: agrotecnologia moderna na produção e comercialização de hortaliças, terceira ed. Editora UFV, Viçosa.

Freitas, F.C.L., Melo, C.A.D., Ferreira, L.R., 2017. Manejo de plantas daninhas, in: Nick, C., Borém, A., (Ed.). Abóboras e morangas do plantio à colheita. Editora UFV, Viçosa, p. 171189.

Lang, M.Y., Ermini, P., 2010. Evaluación de distintas densidades de siembra en un cultivo de zapallo tipo "Anco" (Cucurbita moschata) en la región semiárida Pampeana. Revista de la Facultad de Agronomía de la Universidad Nacional de La Pampa, 21(1), 39-45.

Maciel, C.D.G., Poletine, J.P., Velini, E.D., Belisário, D.R.S., Martins. F.M., Alves, L.S., 2008. Interferência de plantas daninhas no cultivo da melancia. Horticultura Brasileira, 26(1), 107-111.
Madeira, N.R., Amaro, G.B., Melo, R.A.C., Hanashiro, M.M., 2014. Desempenho de cultivares de abóbora híbrida tetsukabuto em sistema plantio direto. Horticultura Brasileira, 31(2), 1526-1531.

Mallet, S.J., Ashley, R.A., 1988. Determination of summer squash's tolerance to weed interference: a critical period study. Northeast Weed Science Society, 42(3), 204-208.

Medeiros, R.D., Moreira, M.A.B., Luz, F.J.F. Oliveira Júnior, J.O.L., 2000. Controle de plantas daninhas na cultura da melancia em Roraima. Horticultura Brasileira 18(3), 450-451.

Nascimento, W.M., Pessoa H., Silva, P., 2011. Produção de Sementes Híbridas de Abóbora do Tipo Tetsukabuto, in: XI Curso sobre Tecnologia de Produção de Sementes de Hortaliças. Porto Alegre, Embrapa Hortaliças.

Nosratti, I., Mahdavi-Rad, S, Heidari, H., Saeidi, M., 2017. Differential tolerance of pumpkin species to bentazon, metribuzin, trifluralin and oxyfluorfen. Planta Daninha, 35(e017165650), 1-9.

Priori, D., Barbieri, R.L., Castro, C.M., Oliveira, A.C., Vilela, J.C.B., Mistura, C.C., 2013. Diversidade genética deCucurbita pepo, C. argyrosperma e C. ficifolia empregando marcadores microssatélites. Horticultura Brasileira 31(3), 361-368.

Sediyama, M.A.N., Vidigal, S.M., Santos, M.R., Mascarenhas, M.H.T., 2009. Cultura da moranga híbrida ou abóbora Tetsukabuto. Belo Horizonte, EPAMIG, 58 p. (Boletim técnico, 92).

Silva, M.G.O., Freitas, F.C.L., Santos, E.C., Mesquita, H.C., Carvalho, D.R., 2013a. Interferência de plantas daninhas na qualidade da melancia nos sistemas de plantio direto e convencional. Revista Caatinga, 26(3), 53-61.

Silva, M.G.O., Freitas, F.C.L., Negreiros, M.Z., Mesquita, H.C., Santana, F.A.O., Lima, M.F.P., 2013b. Manejo de plantas daninhas na cultura da melancia nos sistemas de plantio direto e convencional. Horticultura Brasileira, 31(3), 494-499.

Splawski, C.E., Regnier, E.E., Harrison, S.K., Bennett, M.A., Metzger, J.D., 2016. Weed suppression in pumpkin by mulches composed of organic municipal waste materials. HortScience, 51(6), 720-726.

Tavares, C.A.M., 1999. Abóbora Tetsukabuto. Seed News, 13, 24.

Teófilo, T.M.S., Freitas, F.C.L., Medeiros, J.F., Silva, D.F., Grangeiro, L.C., Tomaz, H.V.Q., 2012. Eficiência no uso da água e interferência de plantas daninhas no meloeiro cultivado nos sistemas de plantio direto e convencional. Planta Daninha, 30(3), 547-556.

Trani, P.E., Passos, F.A., Araújo, H.S., 2014. Calagem e adubação da abobrinha italiana (de moita) (Curcubita pepo), abóbora brasileira (Cucurbita moschata), moranga (Cucurbita máxima) e abóbora japonesa (híbrida). Boletim técnico, 8 p. http://www.iac.sp.gov.br/imagem_informacoestecnologicas/96 .pdf (acessado 15 de janeiro de 2020).

Vidal, R.A., Kruse, N.D., Fleck, N.G., Merotto, J.R., 2000. A seletividade do herbicida fluazifop-p-butil para cucurbitáceas. Planta Daninha, 18(3), 413-417. 
Vidigal, S.M., Pacheco, D.D., Facion, C.E., 2007. Crescimento e acúmulo de nutrientes pela abóbora híbrida tipo Tetsukabuto. Horticultura Brasileira, 25(3), 375-380.
Walters, S.A., Jovem, B.G., 2010. Effect of herbicide and cover crop on weed control in no-tillage jack-o-lantern pumpkin (Cucurbita pepo L.) production. Crop Protection, 29(1), 30-33. 